\title{
Front Matter: Volume 9647
}

, "Front Matter: Volume 9647," Proc. SPIE 9647, Unmanned/Unattended Sensors and Sensor Networks XI; and Advanced Free-Space Optical Communication Techniques and Applications, 964701 (2 November 2015); doi: $10.1117 / 12.2217596$

SPIE. Event: SPIE Security + Defence, 2015, Toulouse, France 


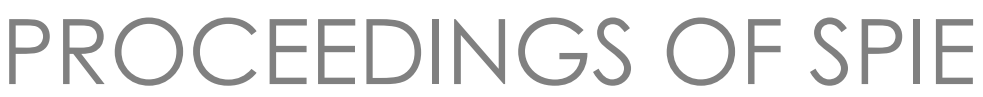

\title{
Unmanned/Unattended Sensors and Sensor Networks XI; and Advanced Free-Space Optical Communication Techniques and Applications
}

\author{
Edward M. Carapezza \\ Panos G. Datskos \\ Christos Tsamis \\ Leslie Laycock \\ Henry J. White \\ Editors
}

23-24 September 2015

Toulouse, France

Sponsored by

SPIE

Cooperating Organisations

European Optical Society

Optitec (France)

Route des Lasers (France)

Published by

SPIE 
The papers in this volume were part of the technical conference cited on the cover and title page. Papers were selected and subject to review by the editors and conference program committee. Some conference presentations may not be available for publication. Additional papers and presentation recordings may be available online in the SPIE Digital Library at SPIEDigitallibrary.org.

The papers reflect the work and thoughts of the authors and are published herein as submitted. The publisher is not responsible for the validity of the information or for any outcomes resulting from reliance thereon.

Please use the following format to cite material from these proceedings:

Author(s), "Title of Paper," in Unmanned/Unattended Sensors and Sensor Networks XI; and Advanced Free-Space Optical Communication Techniques and Applications, edited by Edward M. Carapezza, Panos G. Datskos, Christos Tsamis, Leslie Laycock, Henry J. White, Proceedings of SPIE Vol. 9647 (SPIE, Bellingham, WA, 2015) Six-digit Article CID Number.

ISSN: 0277-786X

ISSN: 1996-756X (electronic)

ISBN: 9781628418576

Published by

SPIE

P.O. Box 10, Bellingham, Washington 98227-0010 USA

Telephone +1 3606763290 (Pacific Time) · Fax +1 3606471445

SPIE.org

Copyright (C) 2015, Society of Photo-Optical Instrumentation Engineers.

Copying of material in this book for internal or personal use, or for the internal or personal use of specific clients, beyond the fair use provisions granted by the U.S. Copyright Law is authorized by SPIE subject to payment of copying fees. The Transactional Reporting Service base fee for this volume is $\$ 18.00$ per article (or portion thereof), which should be paid directly to the Copyright Clearance Center (CCC), 222 Rosewood Drive, Danvers, MA 01923. Payment may also be made electronically through CCC Online at copyright.com. Other copying for republication, resale, advertising or promotion, or any form of systematic or multiple reproduction of any material in this book is prohibited except with permission in writing from the publisher. The CCC fee code is $0277-786 \mathrm{X} / 15 / \$ 18.00$.

Printed in the United States of America.

Publication of record for individual papers is online in the SPIE Digital Library.

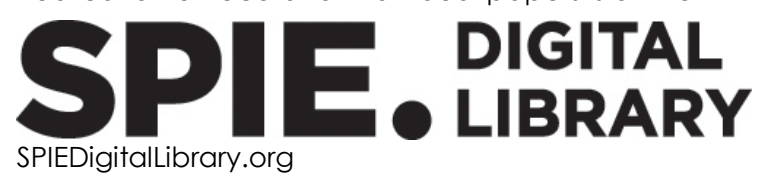

Paper Numbering: Proceedings of SPIE follow an e-First publication model, with papers published first online and then in print. Papers are published as they are submitted and meet publication criteria. A unique citation identifier (CID) number is assigned to each article at the time of the first publication. Utilization of CIDs allows articles to be fully citable as soon as they are published online, and connects the same identifier to all online, print, and electronic versions of the publication. SPIE uses a six-digit CID article numbering system in which:

- The first four digits correspond to the SPIE volume number.

- The last two digits indicate publication order within the volume using a Base 36 numbering system employing both numerals and letters. These two-number sets start with $00,01,02,03$,

$04,05,06,07,08,09,0 \mathrm{~A}, 0 \mathrm{~B} \ldots \mathrm{OZ}$, followed by 10-1Z, 20-2Z, etc.

The CID Number appears on each page of the manuscript. The complete citation is used on the first page, and an abbreviated version on subsequent pages. 


\title{
Contents
}

\author{
$\checkmark \quad$ Authors \\ vii Conference Committee
}

\section{Part A Unmanned/Unattended Sensors and Sensor Networks}

\section{KEYNOTE SESSION I}

964703 Recent development of high power, widely tunable THz quantum cascade laser sources based on difference-frequency generation (Keynote Paper) [9647-19]

\section{DETECTORS, DEVICES, SENSORS AND SENSOR PROCESSING}

964705 Preprocessing and compression of hyperspectral images captured onboard UAVs [9647-3]

964707 The use of composite fence with integrated sensors in security systems [9647-5]

964708 Doppler micro sense and avoid radar [9647-6]

9647 OA Unattended and remote inertial sensors on surface acoustic waves [9647-8]

UNMANNED AND UNATTENDED SENSOR SYSTEMS

9647 OE A system concept for persistent, unmanned, local-area Arctic surveillance [9647-15]

9647 OF Detection and tracking of drones using advanced acoustic cameras [9647-16]

\section{Part B Advanced Free-Space Optical Communication Techniques and Applications}

\section{ADVANCED FREE-SPACE OPTICAL COMMUNICATION I}

$9647 \mathrm{OH}$ Preliminary results of Terabit-per-second long-range free-space optical transmission Experiment THRUST (Invited Paper) [9647-21]

964701 Ground stations for aeronautical and space laser communications at German Aerospace Center [9647-22]

9647 OJ LCT for EDRS: LEO to GEO optical communications at 1,8 Gbps between Alphasat and Sentinel 1a [9647-23] 
ADVANCED FREE-SPACE OPTICAL COMMUNICATION II

9647 OK Evaluation of Error Correcting Code performances of a free space optical communication system between LEO satellite and Ground Station [9647-24]

9647 ON HgCdTe APDs for free space optical communications [9647-27]

ADVANCED FREE-SPACE OPTICAL COMMUNICATION III

$964700 \quad$ A high sensitivity detector for underwater communication systems [9647-28] 


\title{
Authors
}

Numbers in the index correspond to the last two digits of the six-digit citation identifier (CID) article numbering system used in Proceedings of SPIE. The first four digits reflect the volume number. Base 36 numbering is employed for the last two digits and indicates the order of articles within the volume. Numbers start with 00, 01, 02, 03, 04, 05, 06, 07, 08, 09, 0A, OB...0Z, followed by 10-1Z, 20-2Z, etc.

\author{
Abergel, J., ON \\ Artaud, G., OK \\ Asmolova, Olga, 08 \\ Auckloo, A., 00 \\ Bandyopadhyay, N., 03 \\ Busset, Joël, OF \\ Cadirola, Martin, 05 \\ Cheong, J. S., 00 \\ Chochol, M., OK \\ Ciurapinski, W., 07 \\ David, J. P. R., 00 \\ Freund, R., $\mathrm{OH}$ \\ Fuchs, Christian, $\mathrm{OH}, \mathrm{OI}$ \\ Giggenbach, D., $\mathrm{OH}$ \\ Gonwara, Ashok, 08 \\ Heine, F., OJ \\ Herrero, Rolando, 05 \\ Heutschi, Kurt, OF \\ Ingle, Vinay K., 05 \\ Karol, M., 07 \\ Khivrich, Maria, OA \\ Krysa, A. B., 00 \\ Kukaev, Alexander, OA \\ Lacan, J., OK \\ Lasfargues, G., ON \\ LU. Q. Y., 03 \\ Lukyanov, Dmitry, OA \\ Markowski, P., 07 \\ Mata-Calvo, R., $\mathrm{OH}$ \\ McArthur, Bruce A., OE \\ Meyer, R., OJ \\ Molchanov, Pavlo, 08 \\ Moll, Florian, $\mathrm{O}$ \\ Motzigemba, M., OJ \\ Ng, J. S., 00 \\ Nussbaumer, Thomas, OF \\ Ott, Beat, OF \\ Perlot, N., $\mathrm{OH}$ \\ Perrodin, Florian, OF \\ Philipp-May, S., 0J \\ Poliak, J., $\mathrm{OH}$ \\ Razeghi, M., 03 \\ Richter, $\mathrm{T}$., $\mathrm{OH}$ \\ Rissons, A., OK \\ Rothman, J., ON \\ Rühl, Torben, OF \\ Seel, S., OJ \\ Shevchenko, Sergey, OA \\ Shrestha, Amita, 0 l
}

Slivken, S., 03

Szustakowski, M., 07

Telichkin, Roman, OA

Tröndle, D., OJ

Vedrenne, N., OK

Wellig, Peter, OF

Zech, H., OJ

Zyczkowski, M., 07 
Proc. of SPIE Vol. $9647964701-6$

Downloaded From: https://www.spiedigitallibrary.org/conference-proceedings-of-spie on 25 Apr 2023 Terms of Use: https://www.spiedigitallibrary.org/terms-of-use 


\title{
Conference Committee
}

\author{
Symposium Chairs
}

David H. Titterton, UK Defense Academy (United Kingdom)

Symposium Co-chair

Reinhard Ebert, Fraunhofer-Institut für Optronik, Systemtechnik und Bildauswertung (Germany)

\section{Part A: Unmanned/Unattended Sensors and Sensor Networks}

Conference Chairs

Edward M. Carapezza, EMC Consulting LLC (United States)

Panos G. Datskos, Oak Ridge National Laboratory (United States)

Christos Tsamis, National Center for Scientific Research Demokritos (Greece)

\section{Conference Program Committee}

Mehdi F. Anwar, University of Connecticut (United States)

Mark E. Campbell, Cornell University (United States)

Pierre J. Corriveau, Naval Undersea Warfare Center (United States)

Sachi V. Desai, U.S. Army Armament Research, Development and Engineering Center (United States)

John M. Dolan, Carnegie Mellon University (United States)

Grant R. Gerhart, Consultant (United States)

Todd M. Hintz, Space and Naval Warfare Systems Command (United States)

Myron E. Hohil, U.S. Army Armament Research, Development and Engineering Center (United States)

Ivan Kadar, Interlink Systems Sciences, Inc. (United States)

Tariq Manzur, Naval Undersea Warfare Center (United States)

George C. McNamara, Naval Undersea Warfare Center (United States)

Andre Samberg, Sec-Control Innovation (Finland)

Nino Srour, U.S. Army Research Laboratory (United States)

Huub A.J.M. van Hoof, TNO Defence, Security and Safety

(Netherlands) 


\title{
Part B: Advanced Free-Space Optical Communication Techniques and Applications
}

\author{
Conference Chairs \\ Leslie Laycock, BAE Systems (United Kingdom) \\ Henry J. White, BAE Systems (United Kingdom)
}

\section{Conference Program Committee}

G. Charmaine Gilbreath, U.S. Naval Research Laboratory (United States)

Andrew R. Harvey, University of Glasgow (United Kingdom)

Florian Moll, Deutsches Zentrum für Luft- und Raumfahrt e.V. (Germany)

Dominic C. O'Brien, University of Oxford (United Kingdom)

Angélique Rissons, Institut Supérieur de l'Aéronautique et de l'Espace (France)

Andrew M. Scott, QinetiQ Ltd. (United Kingdom)

Zoran Sodnik, European Space Research and Technology Center (Netherlands)

Ian Underwood, The University of Edinburgh (United Kingdom) 